\title{
Playing with Fire: Islamism and politics in Bangladesh
}

[SF] blogs.Ise.ac.uk/southasia/2015/09/24/playing-with-fire-islamism-and-politics-in-bangladesh/

The news yesterday that an Islamic militant group in Bangladesh had published a 'global hitlist' of atheist bloggers follows a series of brutal activist murders over the last year and a half. Martin Griffiths and Mubashar Hasan argue that increasing influence of Islamist groups can be linked to successive governments in Bangladesh moving away from the promise of secularism that underpinned the creation of the country.

Over the past 20 years, an influential body of conservative scholarship by Samuel Huntington, Bernard Lewis, Roger Scruton and Paul Berman has focused on the alleged conflict between Islam and the West. Following widespread criticism of this scholarship, most notably by Amartya Sen and Edward Said, a number of commentators such as John Esposito, Abdullahi Ahmed An-Na`im, Michael D Driessen, Jillian Schwedler revised its core assumptions to claim instead that the real conflict is between democracy within Muslim societies and the political ideology of Islamism. But even this idea has been challenged by a number of scholars including Oliver Roy and Asef Bayat, who have identified the notion of 'post-Islamism', and the potential subordination of religion to the demands of democratic competition within Muslim societies such as Indonesia and Turkey.

However, the debate is limited insofar as it ignores a third possibility, which occurs when a government of an allegedly secular state promotes Islam for its own legitimacy (both domestic and international) and as a source of national identity. Pakistan is an excellent example of this phenomenon, and Bangladesh is moving in this direction. In the absence of an authoritative interpretation of how religion can coexist with liberal freedoms and basic human rights, the use of religion by politicians for opportunistic reasons creates the space for more radical (and violent) groups to influence the political game.

The invocation of religion for political legitimacy in Bangladesh is in a significant part driven by a cynical opportunism among a ruling elite that cannot deliver real development for the country. Corruption has reached alarming levels in all segments of society as increasing nepotism through partisan political preferences has resulted in growing frustration among the populace. While globalisation has brought economic opportunities to some, it has also widened income disparities. This bleak situation creates fertile ground for the radicalisation of frustrated minds to which the vision of Islamic justice has some appeal.

Conflict waged by various Bangladeshi Islamist groups such as Hizbut Tahrir, Hefazat e Islam, Jamaat e Islam, Ansarullah Bangla Team and Jamaatul Mujahedeen may be interpreted as a form of resistance against the impact of global capitalism on Bangladesh. Perhaps surprisingly given the high levels of corruption and poor governance, Bangladesh has experienced moderately good economic growth of around 5 per cent per annum over the past decade. The primary reason for this is the fact Bangladesh is a classic case of a coastal low income country with few resources. Its development has therefore been driven by the export of labour-intensive manufactures (such as the clothing) and services. In this context, the government does not have to clean up its performance in order to preside over some economic success. As Paul Collier has noted,

"the government merely has to avoid doing harm rather than actively do much good. Exporters simply need an environment of modest taxation, macroeconomic stability, and a few transport facilities".

However, this strategy is unlikely to be sustainable over the long term and the mainstream political parties are failing to tackle growing discontent with the state of the economy. Nearly half the population is between 15 and 24 years of age, and at present growth rates, the total population of 125 million will double in less than 30 years. As things 
currently stand, the number jobs and opportunities will not keep pace with the increasing demand, creating a setting similar to that of several Arab countries where young people have been drawn to radical political projects against a backdrop of limited jobs, rising inequality and corruption.

The government's failure to provide and regulate basic public goods, particularly education, also allows radical religious groups to grow their support. Bangladesh has both private Quomi madrassahs and state-sponsored Alia madrassahs. Whilst the latter follow a syllabus that includes subjects such as English, science and mathematics, the former are not subject to regulation. Today there are estimated 6,500 Quomi madrassahs in Bangladesh, enrolling almost 1.5 million students. Despite the considerable success of overseas non-governmental organisations in offering educational opportunities in addition to the formal schooling system provided by the state, there are millions of potential students who remain outside the state system and vulnerable to radicalisation.

The rise of Hefazat e Islam is a good illustration of a radical organisation which has used the unregulated education system to build support and is now aggressively seeking to influence policy. The grouping formed out of Quomi madrassah lobby to oppose any moves to give Muslim women equal rights in inheritance or to reform Quomi private education. In 2013 Hefazat went even further and issued its 13-point charter of demands, including the promulgation of a blasphemy law with a provision for the death penalty, the scrapping of laws on women's rights and education, declaring members of the Ahmedya community non-Muslims, banning Christian missionary activities (especially in the Chittagong Hill Tracts), and dismantling sculptures erected in public places considered by the Hefazat as unIslamic symbols. Hefazat represents a very narrow, obscurantist view of Islam, akin to the Taliban in Pakistan and Afghanistan. However, its march in Dhaka on 5 May 2013 drew a crowd of nearly half a million madrassah students, teachers and sympathisers and the government had to apply considerable force to eject the protesters from their sitin. Hefazat's ability to mobilise such significant numbers in 2013 suggests that the Quomi madrassahs, previously considered by the political elites as the abode of the poor and neglected, are becoming a potent political force.

The upshot of these developments is that disaffection with both political parties is widespread, while the support base of Islamists is growing steadily. Policies that are good for export-oriented development, such as low taxes, are hardly conducive to regulating and improving the education system. Although the majority of Bangladeshis believe that the role of Islam in Bangladesh should not be political (in a context marked by a great diversity of Islamic forms, ranging from Wahhabism and Salafism to Sufism), there is a strong possibility that the Islamists will become a formidable political force in Bangladesh in the not-too-distant future if political parties continue to mobilise Islam for political ends and neglect their broader responsibilities.

This is an abridged and revised version of a research article originally published in the Asian Journal of Political Science 23(2):226-241.

Image credit: flickr/Damien Thorne CC BY-NC-ND 2.0.

Note: This article gives the views of the author, and not the position of the South Asia @ LSE blog, nor of the London School of Economics. Please read ourcomments policy before posting.

\section{About the Authors}

Martin Griffiths is Professor of International Studies at Flinders University, Australia. He was previously Head of the School of Government and International Relations at Griffith University. Martin is a graduate of the London School of Economics (BSc Hons), Keele University (MA), and the University of British Columbia in Vancouver, Canada, where he completed his Ph.D. He has published eleven books, numerous chapters in edited collections, as well as journal articles in leading journals such as Millennium, The Review of International Studies, The Australian Journal of International Affairs, The Australian Journal of Politics and History, and The Australian Journal of Political Science. Outside Flinders, Martin is a Visiting Fellow with the Centre for Defence and Strategic Studies in Canberra. 
Mubashar Hasan is a research fellow of Bangladesh Institute of Social Research Trust and a PhD Candidate at the School of Government and International Relations, Griffith University, Australia. He is the founder of alochonaa.com, a politics, culture and IR blog, and tweets @mubashardhaka.

- Copyright @ 2016 London School of Economics 